\title{
対話型教示エージェントモデル構築に向けた 漫才対話のマルチモーダル分析”
}

\author{
岡本 雅史 $* 1 \cdot$ 大庭 真人 $* 1 \cdot$ 榎本 美香 $* 2 \cdot$ 飯田 仁 *2
}

\begin{abstract}
本研究は, 漫才対話が二者間での対話形式を取りながら第三者である観客への情報伝達を可能とする 〈オープンコミュニケーション〉構造を持つことに着目し, 発話・視線・姿勢などのマルチモーダルな要素 間の相互作用の分析を行うことにより，二体の擬人化エージェントの対話を通じてユーザに効果的にイン ストラクションを行う対話型教示エージェントモデルを構築する上で有用な知見を得ることを目的とする. 特にオープンコミュニケーションの大きな特徴の一つであるコミュニケーションの「外部指向性」に焦点 を当て, 非明示的な観客への情報伝達である「外部指向性」と直接的に観客への働きかけを行う「内部指 向性」の両者が, どのように演者内のマルチモーダルな振る舞いと演者間のインタラクションによって実 現されているかをプロの漫才師の対話映像の分析から探った。結果として, オープンコミュニケーション に打ける指向性の顕在化は, 今回分析対象とした二組の漫才コンビ間で異なる形式を持つことが明らかと なり,オープンコミュニケーションの指向性を捉える上でマルチモーダルなチャネル間の相互関係が重要 な役割を果たしていることがわかった。
\end{abstract}

キーワード：漫才対話, オープンコミュニケーション, マルチモダリティ, 外部指向性, 対話型教示エー ジェント

\section{1. はじめに}

擬人化エージェントによる情報提供システムの開発 が近年盛んに行われている。代表的なところでは，主 に顔部分のみでユーザへの情報提供や対話を行う Ananovaエージェント[1]やGalatea[2]，両手を含め た上半身による非言語動作が可能な Rea[3]やMACK [4]などがある。これらのエージェントはいずれも ユーザとのインタラクションを単独で行うことが想定 されている。

一方, 複数のエージェント同士の対話によって情報 提供を行うシステムも注目されており，POC caster [5]やEgoChat[6]などいくつかのシステムが存在す る。しかしながら，ユーザとの対話だけに留まらず エージェント同士の自然な対話を実現するために，ど のような非言語動作をどの時点で取るべきかという点 はまだ明らかではない。

本研究は, こうした背景から擬人化エージェント同 士の対話によってユーザに情報提供を行うシステムの

$\dagger$ Multimodal Analysis of Manzai Dialogue Toward Constructing a Dialogue- Based Instructional Agent Model

Masashi OKAMOTO, Masato OHBA, Mika ENOMOTO and Hitoshi IIDA

*1 東京工科大学 片柳研究所

Katayanagi Advanced Research Laboratories, Tokyo University of Technology

*2 東京工科大学 メディア学部

Dept. of Media Science, Tokyo University of Technology
開発を目指し，人間同士の対話における発話内容と非 言語的動作の間の相互関係，および複数の非言語モダ リティ間の関係を明らかにすることを目的とする。特 に，二者間の対話によって第三者であるユーザへ情報 伝達を行うことは通常の二者間による閉じられた対話 とは異なる性質を持つことが予想されるので, 本稿で はこれをくオープンコミュニケーション〉と名付け，そ の雛形としてプロの演者による漫才対話を分析する.

ここで分析対象として漫才対話を取り上げる理由は 二つある。一つは，互いに対話を行うことによって観 客としてのユーザに有用な情報を伝達する教示エー ジェント (本研究ではこれを「対話型教示エージェン ト」と呼ぶ)を設計する上で，エージェントの身体動作 への制約を最小限にしたいという欲求である。例え ば，最近のテレビの報道番組に見られるようなメイン のニュースキャスターにサブキャスター(もしくはコ メンテーター)が加わったセッティングに打いては， 基本的にキャスターたちは固定されたテーブルに着席 して扔り，身体動作を十分に利用して情報伝達を行っ ているとは言いがたい。また，その結果としてそうし た報道番組では，視聴者に伝える情報を焦点化するた めにズームアップやショットの切り替えなどのカメラ ワークを利用せざるを得ない。しかしながら，CGに よる擬人化エージェントの身体動作の表現力の向上が 期待され，さらには実世界ロボットへの応用も視野に 入れるとすれば，顔や上半身だけでなく全身を用いた 
コミュニケーションが可能なエージェントに対する需 要は今後ますます高まると考えられる。㘯の意味で, 漫才という二人の対話者が共に立っている状態で情報 伝達を行うコミュニケーションスタイルは, 非言語 チャネルとしての身体動作を十分に活用している好例 であり，その分析は対話型教示エージェントモデル構 築において重要な知見をもたらすであろうことが期待 できる.

もう一つの理由として, 漫才が基本的には二者間の 対話のみによって情報伝達を行うスタイルであり，ビ デオ映像やスライド, ポスターなど他の情報コンテン ツが介在する必要がないことが挙げられる。この特徴 により，先に挙げた従来システムのほとんど全てが擬 人化エージェント以外の情報コンテンツを介在させる システムであるため, どうしてもシステム内でのエー ジェントの存在意義が付加的なものに留まる傾向が強 く, またシステムの評価が情報コンテンツの内容や演 出手法，様式などに依存しやすいというような多くの 欠点を回避することができる。もちろん我々は教示シ ステムにおけるそうした情報コンテンツの有用性を否 定するものではないが, 漫才対話のコミュニケーショ ンスタイルを範とすることによって, 対話型教示エー ジェントモデルの構築をエージェントと情報コンテン ツの協調を実現するためのシステムデザインの設計と 独立に行うことができることの利点は大きい，

こうした問題意識と研究観点に基づき, 我々は漫才 対話の分析が真に沉用的な対話型教示エージェントモ デルの構築を目指す第一歩として大きな意義を持つと 考える.

\section{2 . オープンコミュニケーションとしての 教示対話}

本稿で提起するくオープンコミュニケーション〉概念 の射程は三つある。一つは, 先に述べたように対話形 式でのやり取りでありながらその指向性が直接の参与 者だけではなく外部にも向けられるという, コミュニ ケーションの「外部指向性」である。これは, 特定の受 け手への明示的な情報伝達をコミュニケーションの 「内部指向性」の現れであるとするならば，それに対す る非明示的な情報伝達であると捉えることができる.

例えば，教育番組や料理番組などで二人の解説者が 対話することで視聴者への情報提供を行う場合, 発話 の明示的な受け手はもう一方の対話者か視聴者のどち らかとなるが，対話相手に向けられている場合であり ながら実際には非明示的に視聴者への情報提供となっ ている場合も多い, 従って, 視聴者への情報伝達は直 接的に視聴者を受け手として指定する内部指向的発話
と，間接的に視聴者に向けられた外部指向的発話の 2 種類が存在することとなる。

これに関して, Clark \& Carlson[7]は特定の受け手 (addressee)に対してある発語内行為を遂行する際 に, 参与者全員にその発語内行為を知らせるという参 与者指向的な (participant-directed) 発語内行為の存在 を指摘し，これを 'informative’ と名付けた. Clarkら は全ての受け手指向的 (addressee-directed) な発語内 行為の遂行がこのinformativeに基づいていると主張 したが, 我々はコミュニケーションの外部指向性を informativeという特定の固定化された発語内行為と 考えるよりも, むしろ発話が明示的に特定する受け手 への情報伝達としての内部指向性と対比させ, あらゆ る発話がそうした外部指向性と内部指向性の両方の性 質を持っていることを強調したい。つまり，ある発話 が内部指向性よりも外部指向性が強く現れている一 方, また別の発話はその逆の傾向を持ち, また外部指 向性が強い発話同士であってもその強さが異なってい るというような, グレイディエンスを持った性質であ ると考える。

一方，テレビでの漫才番組に見られるように，二人 の対話者と観客が生み出している「場」そのものの提示 が, この外部指向性を包含した形で新たな観察者であ る視聴者への認知的効果を生み出す可能性もこのオー プンコミュニケーションの射程に含まれる。つまり， 漫才対話を映像コンテンッとして視聴者に提供する場 合, 自然なタイミングによる観客の笑い声や拍手など の存在が視聴者へのく共感チャネル $[8]$ としての機能 を果たし，「場」の外にいる視聴者のインボルブメント (認知的関与)を向上させるという, オープンコミュニ ケーションのメタ的な側面である。

そして最後に，いわゆる漫才におけるボケに典型的 に見られるような, 伝達すべき情報の過不足や誤情報 などの意図的な提示により，相手にッッコミという形 での訂正や応答をアフォードするという, 情報伝達に おける開かれた相互行為性も視野に入っている。これ は教示コンテンツに拈いてはユーザの代理として質問 を行うエージェントを設計する上で重要な示唆を与え ると考えられる。

本稿では上記の三つの観点のうち, 特に最初の外部 指向性に着目する。教示対話を行うエージェントモデ ルを構築する上で, 外部のユーザを直接的に指向する 「内部指向性」と, 対話相手のエージェントに向けられ ていながら間接的にユーザを指向する「外部指向性」の 二つのフェーズが, どのような言語的特徴と非言語的 特徴によって顕在化するかを知る必要がある。特に漫 才の非言語的特徴においては, テレビの漫才番組の観 
察から，演者の視線だけでなく身体の方向もこうした 指向性の選択に重要な役割を果たしていると考えられ るので, 本研究ではこの演者の視線と姿勢 (ポスチャ) の関係に注目する。

従って, 本稿ではプロの漫才師の対話に扎ける言語 チャネルと非言語チャネルの指向性の相互関係, さらに は演者の視線と姿勢という二つの非言語モダリティ ${ }^{1}$ 間の同期・非同期についてそれぞれ分析することで, 漫才対話のオープンコミュニケーション構造の指向性 を明らかにする。

\section{3. 関連研究}

漫才対話を工学的に実現しようとする研究がいくつ かある。林ら [9] はロボット同士の対話を見せること による観察者への情報伝達モデルとして「社会的受動 (passive-social) メディア」を提案し，実際に漫才を行 うロボットの対話による情報伝達とテレビによる情報 伝達の比較実験を行っている。また，スコギンズら [10]や川嶋ら [11]は，自身が作成した漫才対話コーパ スの分析に基づき, 発話のDA (dialog act) と発話移行 区間長の関係から発話のオーバーラップとポーズの取 り方を動的に制御するシステムデザインを提案してい る.

こうした研究では基本的に発話タイミングにのみ関 心が置かれ，それ以外の非言語的な振る舞いの分析は あまりなされていない。また林らの「社会的受動メ ディア」は本研究で提案するくオープンコミュニケー ション〉と近い概念であるが, 前者が二者間の対話に より観察者への情報伝達を果たす上で固定化された参 与構造, つまりロボット同士の閉じた会話を前提とし ているのに対し，本研究は言語的・非言語的なモダリ ティ間の相互作用がもたらす参与構造の動的な変化, つまり外部指向性と内部指向性の円滑な遷移を観察す る点で異なる。

また, 本研究の最終目的である対話型教示エージェ ントモデルの構築に関連する研究として, 渡辺ら [12] [13]や山本ら [14]が開発している音声駆動型身体引き 込みキャラクタ InterActorや, 複数のInterActorを仮 想教室空間に配置したSAKURAの研究がある。これら 一連の研究は, 意味情報を含まない音声情報のみを入

1 本稿では一般的に混同されやすい「(言語・非言語) チャネル」 と「(非言語) モダリティ」を区別して用いている．前者は情 報伝達に打ける受信者の感覚器の区別に基づき, 後者は発信 者による表現の様態に基づく. 例えば, 本稿で中心的に取り上 げる視線や姿勢は, どちらも受信者の視覚を通して認知され る同一の「非言語チャネル」に属するが, 発信者の表現様態と しては区別されるため, 個別に指示する際は「非言語モダリ ティ」と呼ぶ.
力として身体動作を実現する点，上半身のみを持った エージェントである点, さらには主に聞き手の反応を 再現する目的でなされている点など, 本研究が射程と している対話型教示エージェントモデルに完全に合致 するものではないが, 非言語動作と教示効果との関係 について示唆に富むものと考える。特に, SAKURAに おける生徒役のエージェントがユーザに対し背を向け ていることによって心理的な引き込みを確立している 点は, 本稿の第一著者による従来研究においても認知 的な観点からその効果が指摘されており [8][15], 2 節で述べた観客モデルを含むオープンコミュニケー ションのメタ的な㑯面を実現する上での重要なポイン トとなるであろう。

一方，漫才対話の言語的分析としては，金澤ら [16] が古典的な漫才の言語的特徴として「はいはい」のよう な「合いの手」や, 相手の発話の一部の「繰り返し」と いった「合いの手的」要素の存在を挙げ, 話のスジをテ ンポ良く進行させる機能を持っていることを指摘して いる。ささらに金澤らは，これまでとは異なる新しい漫 才スタイルで大人気となった漫才コンビ「ダウンタウ ン」の登場を契機として ${ }^{2}$, 最近の漫才ではこうした要 素が失われ, より日常会話に近づいていること $(=フ$ リートーク化)を指摘する。例えば, 金澤らが挙げて いるダウンタウンの漫才の例では, 話のスジを進行さ せるための合いの手的要素の代わりに,「うん」や 「あー」といったうなずきによるあいづちが多く見ら れ，話芸としてテンポが悪くなることと引き換えに日 常の自然な会話への接近を示している.

また, 清原[17]は漫才における聴衆の役割変化につ いて考察し, 漫才コンビの説明役による情報提供の 〈純粋な受け手〉, 発話とイメージの間の違和感を感じ る〈情報判断を交えた受け手〉, そしてくツッコミへの 同調者〉としての 3 つの役割を提案している。さら に, ツッコミ発話は原則として「です・ます」表現を伴 わないという重要な指摘も行っている.

本稿ではこうした漫才対話の言語的分析の知見を発 話の指向性の特定に反映させ, 従来研究ではなされて いなかった漫才の非言語的側面と併せて分析を行うこ とで, 対話型教示エージェントモデル構築のための有 用な知見を得たいと考える。

2 ダウンタウンが関西地方で人気を博したのは1980年代後半で あるが, 東京に進出して全国的な人気を獲得したのは 1990 年 代初頭であるため, 恐らくこの頃から新しいスタイルの漫才 が流行していったと予想される. 


\section{4. データ分析}

\section{1 データ}

分析データとして今回は二つの異なる漫才スタイル を持つ漫才師の映像を用いた。一つは古典的なしゃべ くり漫才(漫才内コントを含む)を得意とするべテラン 漫才コンビ「オール阪神・巨人(以下, AHK)」の『ホー

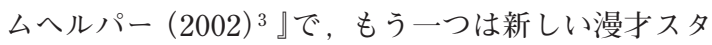
イルで人気を集めている若手の「チュートリアル(以 下，TR)」の『冷蔵庫 $(2006)^{4}$ 』という漫才映像である. 分析のため, サイズを $320 \times 240$ ピクセル，コーデッ クをH.263に，フレームレートを29.94fpsにそれぞれ 変換した ${ }^{5}$ 。また，時間長はそれぞれ 428 秒と 427 秒で ある。

なお，上記の対照的な 2 組を取り上げた理由は， AHKは先に挙げた金澤ら [16]の研究でも引用されて いるように, 漫才特有と考えられる「合いの手的」要素 を効果的に活用している古典的スタイルの代表例であ ると考えられ，一方TRはダウンタウン以降現在の若 手の漫才スタイルの主流である, 日常会話的ないしは フリートーク的な漫才スタイルを用いて打り，漫才分 析データとして取り上げる上で最小限のカップリング となると考えたからである。また，AHKは上方漫才 大賞, 上方扮笑い大賞, 花王名人大賞など, 主要なコ ンテストで複数回グランプリを獲得しており, TRも 2006年にM- 1 グランプリで優勝した経験があること から，実力・人気ともに申し分ないものと判断した。

\section{2 分析手法}

まず，上記の映像の音声トラックからMultiTrans [18］を用いてセリフの書き起こしを行った。次にAnvil[19]を用いて非言語動作のアノテーションを行っ た(図 1$)^{6}$.これらの作業は著者たちの教示に基づい て大学生 2 名によって重畳的に行われ, 作業結果の相 違点が生じた場合は，第一著者と作業者 2 名との合議 の上で第一著者が適切なタグおよびセグメント境界を 判断した。

本研究で用意したタグセットは, speech (発話)，

3 DVD『オール阪神・巨人一僕らは浪速の漫才師 (2005)』 (YOSHIMOTO R and C CO., Ltd.) 所收.

4 DVD『チュートリアリズム (2006)』（YOSHIMOTO R and C CO., Ltd.) 所収. なお, 正式な漫才タイトルは付けられていな かったため, 内容から著者たちが判断した.

5 アノテーションはI フレーム毎に行われるため, これに伴い 理論上の精度は約 $33.4 \mathrm{~ms}$ となるが, 元の映像ソースが DVDで あり，さらには変換に用いたコーデックの性質上フレーム間 圧縮は避けられず，実際の精度はそれよりも劣る。

6 著作権及び肖像権に配慮し, 眓中の漫才映像の画像について は適宜修正を行った。 gaze (視線), posture (姿勢), orientation (発話の指 向性), BP(非言語行動パターン; behavior pattern), function (発話の意味機能), laughter (観客の笑い)の 7 タイプであるが, 今回は発話の指向性と視線・姿 勢, および視線と姿勢の組み合わせとしての非言語行 動パターンの相互関係を観察することが中心であるの で，最後の 2 つのグは分析に用いなかった。

speechタイプについては, 発話の切れ目を $200 \mathrm{~ms}$ 以 上の無音区間が挟まった箇所を一つのセグメントと し，セグメント内の発話の書き起こしを行った。ま た, gazeタイプについては［相方］·[観客］・[上］・ [下] - [後] · [外] · [その他 $] \cdot$ [unidentified] 8 種 類の值のいずれかを付与し, postureタイプについ

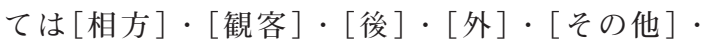
[unidentified]の 6 種類のいずれかの值を付与した. なお，映像からは視線の正確な同定は困難であるの で, 明らかに視線と顔の向きが一致しない場合を除 き, 顔の向きでgazeタイプのアノテーションを行っ た。

さらに非言語行動パターンは, 視線と姿勢がともに 観客に向けられているものを[BP1]，ともに相方に向 けられているものを [BP2], 視線が観客に向けられ姿 勢が相方に向けられているものを[BP3]，その逆の組 み合わせのものを $[\mathrm{BP} 4]$ とし, その他の組み合わせを [その他], 確認できないものを[unidentified]とし た。以上のタグに拉ける [unidentified] タグはいずれ のタイプに打いても, 市販映像に不可避なカメラワー クとショット編集のために作業者がどうしても確認で きないものに対して付与している.

最後に, orientationタイプについては[相方］・[観 客]・[その他]の 3 種類としたが, その付与基準につ いては4.3.3節で述べる。

\section{3 分析結果}

\subsection{1 視線・姿勢配分の分析}

まず, AHKの漫才映像に打ける二人の演者の視線 の方向と姿勢の方向を, それぞれについて観客へ向け たものと相方へ向けたものに分類し，その合計時間と 映像全体からの比率を求めた。ささに, 分析対象とし たデータが前半は通常のしゃべくり漫才 (228秒), 後 半がコント (200秒) という構成になっていたため, 前 者を漫才モード (M-mode), 後者をコントモード (Cmode)とし，それぞれのモードに打ける分布も併せて 調べた（表 1 ).

なお，漫才モードとコントモードの区別に際し，本 研究では暫定的に, 漫才モードを「演者が現実世界に おける自身の社会的パーソナリティを維持しながら現 


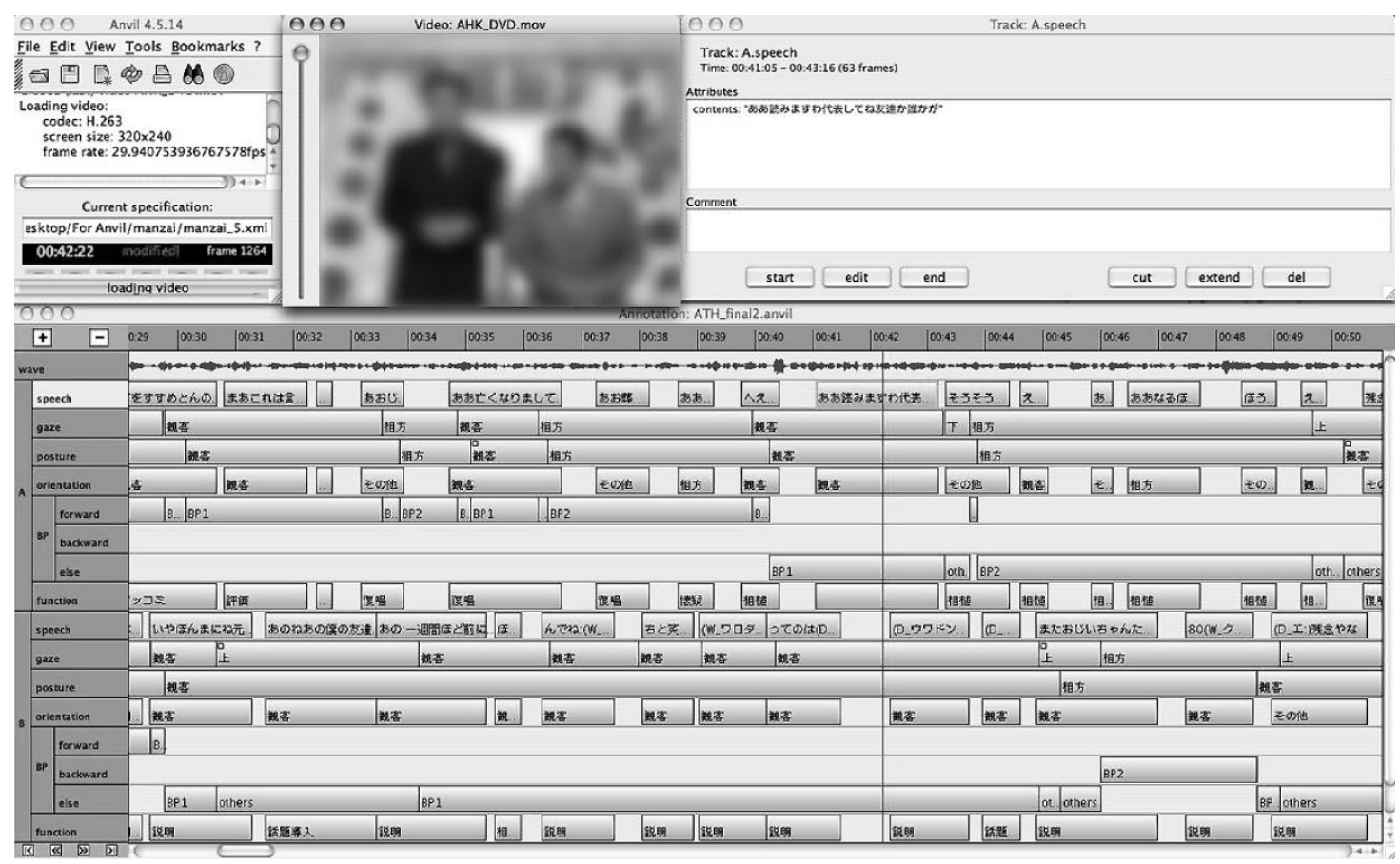

図 1 Anvil によるアノテーション画面の実例

表 1 AHKの視線 / 姿勢配分

\begin{tabular}{|c|c|c|c|c|c|}
\hline \multirow[b]{2}{*}{ 演者 } & \multirow[b]{2}{*}{ 方向 } & \multicolumn{2}{|c|}{ 視線 (M-mode/C-mode) } & \multicolumn{2}{|c|}{ 姿勢 $(\mathrm{M}$-mode/C-mode) } \\
\hline & & 観客 & 相方 & 観客 & 相方 \\
\hline $\mathrm{AH}$ & $\begin{array}{c}\text { 合計時間 } \\
\text { [sec }] \\
\text { 全体比 } \\
\text { (モード比) [\%] }\end{array}$ & $\begin{array}{c}95.86 \\
(93.55 / 2.30) \\
22.41 \\
(40.99 / 1.15)\end{array}$ & $\begin{array}{c}205.67 \\
(88.58 / 117.10) \\
48.08 \\
(38.81 / 58.68)\end{array}$ & $\begin{array}{c}190.08 \\
(111.09 / 78.99) \\
44.43 \\
(48.67 / 39.58)\end{array}$ & $\begin{array}{c}161.85 \\
(80.26 / 81.39) \\
37.79 \\
(35.16 / 40.79)\end{array}$ \\
\hline $\mathrm{AK}$ & $\begin{array}{c}\text { 合計時間 } \\
\text { [sec }] \\
\text { 全体比 } \\
\text { (モード比) [\%] }\end{array}$ & $\begin{array}{c}120.30 \\
(118.23 / 2.07) \\
28.12 \\
(51.80 / 1.04)\end{array}$ & $\begin{array}{c}157.41 \\
(46.39 / 111.02) \\
36.79 \\
(20.32 / 55.63)\end{array}$ & $\begin{array}{c}199.89 \\
(166.86 / 33.03) \\
46.72 \\
(73.11 / 16.55)\end{array}$ & $\begin{array}{c}167.16 \\
(38.78 / 128.39) \\
39.07 \\
(16.99 / 64.33)\end{array}$ \\
\hline
\end{tabular}

実の舞台上で対話を行っている状態〕，コントモード を「演者が現在時ならびに現実の舞台とは異なる時空 間を設定し，(多くの場合)自身とは異なるキャラクタ を演じている状態」と規定しておく．

まず, AHKでは基本的にオール巨人(以下， AK)が ボケ役を演じ，オール阪神(以下， $\mathrm{AH}$ ) がッッコミ役 を演ずるのであるが，視線と姿勢それぞれの合計時間 から観察すると，全体的な傾向として，両者とも視線 は相方に向けられることが多く, 姿勢は観客に向けら

7 ここで言う「社会的パーソナリティ」とは, 漫才師の場合はそ の芸名において活動を期待される人格であり，本名でなされ る私生活上の人格とは区別している.
れることが多いことが分かった。

さらに各状態の持続時間を従属変数として，3 要因 の分散分析 (演者 (2) Xモード (2) X視線/姿勢方向 (2)) を行い，視線 $(n=196)$ と姿勢 $(n=164)$ のそれぞ れについて被験者内要因の分析を行った。

その結果, 視線については, モードと方向との交互 作用 $(F(1,188)=6.95, p<.01)$ が有意であったが，他 の要因については有意差がなかった。これはAK・AH のどちらにおいても, 視線は漫才モードでは観客に向 いている時間が長く，コントモードにおいては相方に 向いている時間が長いことを示唆している。このよう に, 視線の方向は 2 つのモードによって明確に切り替 
えられていることが示された。

一方，姿勢については，演者に主効果があった $(F$ $(1,156)=10.67, p<.0005)$.これは，ボケ役のAKが 相方のAHよりも長く同じ姿勢を維持していることを 示している. 交互作用については, 視線と同様にモー ドと方向との間 $(F(1,156)=16.85, p<.0001)$ に有意 な差があり, さらに, 演者とモードと方向の 3 要因間 $(F(1,156)=11.25, p<.001)$ にも有意差があった。こ れによって, 漫才モードでは観客の方向を向いている 時間が長く，コントモードでは相方を向いている時間 が長いことが確認され，さらに 3 要因間の交互作用が 有意であることから, 姿勢については総じて, AKが モードによって向く方向をはっきりと切り替えるのに 対し，AHはAKほどモードごとに向く方向を明確に切 り替えておらず，どちらのモードにおいても細かく向 きを変えていることが分かった。

次に, TRの視線・姿勢配分に対しても同様に定量 的分析を行った。 TRの漫才は全時間がしゃべくり漫 才となっていたため, モード別の分析は行わなかっ た。その結果を表 2 に記す。なお，TRでは一貫して 福田 (以下, TF) がッッコミ役となり, 徳井(以下, TT)がボケ役を演じている.

視線と姿勢それぞれの合計時間からの観察により TRの両演者とも, 視線は相方に 8 割近く向けられ， 観客に向けられるのは $8 \%$ 以下に過ぎないことが明ら かとなった。一方, 姿勢は 9 割前後観客に向けられ， 相方に姿勢が向けられるのはTTが $14 \%$ 程度, TFに 至っては $0.3 \% に$ 過ぎない。この傾向自体はAHKの全 体的傾向と共通するものであるが，かなり極端な偏り を見せていると言える。

さらに視線打よび姿勢について，それぞれ演者 (2) X視線/姿勢方向 (2)の 2 要因の分散分析を行ったとこ 万, 視線についてのみ, 方向 $(F(1,174)=20.34, p<$ .00005)に主効果の有意差が見られた。従って, 視線 については，相方の方向を見つめている時間の方がは るかに長いことが分かる。ただ, 視線は細かく移動が 起こっており, 生起回数が 175 回と比較的多いのに対

表 2 TRの視線/姿勢配分

\begin{tabular}{|c|c|c|c|c|c|}
\hline & & \multicolumn{2}{|c|}{ 視線 } & \multicolumn{2}{|c|}{ 姿勢 } \\
\hline 演者 & 方向 & 観客 & 相方 & 観客 & 相方 \\
\hline $\mathrm{TF}$ & $\begin{array}{c}\text { 合計時間 [sec] } \\
\text { 全体比 [\%] }\end{array}$ & $\begin{array}{l}31.86 \\
7.45\end{array}$ & $\begin{array}{c}341.64 \\
79.93\end{array}$ & $\begin{array}{c}395.49 \\
92.53\end{array}$ & $\begin{array}{l}1.30 \\
0.30\end{array}$ \\
\hline TT & $\begin{array}{l}\text { 合計時間 [sec] } \\
\text { 全体比 [\%] }\end{array}$ & $\begin{array}{c}32.13 \\
7.52\end{array}$ & $\begin{array}{l}339.67 \\
79.47\end{array}$ & $\begin{array}{l}356.79 \\
83.48\end{array}$ & $\begin{array}{l}59.75 \\
13.98\end{array}$ \\
\hline
\end{tabular}

し，姿勢については，そもそも生起回数が 25 回と少な く, 検定に耐えうるほどの回数ではなかった。そのた め実際には, 姿勢は観客に向けられている時間の方が はるかに長いにも関わらず統計的に有意な差を得るこ とはできなかった。 また, 視線と姿勢じちらについて もボケ役・ツッコミ役ともに同様の振る舞いをしてい ることが示された。総じて, TRにおいては, 同一の 「観客に向けた姿勢, 相方に向けた視線」という体勢を 取り続けていることが分かる.

まとめると, AHKでは全体としては視線が相方に 向けられ, 姿勢が観客に向けられるが, 漫才モードと コントモードに分けて比較すると, AKは漫才モード では視線も姿勢も観客に向けており, コントモードで は視線も姿勢も相方に向けているのに対し, TRでは 両者とも, 視線は相方に向けられる時間が長く, 姿勢 はほとんどが観客に向けられていると言える。

\subsection{2 非言語行動パターンの分析}

前節では視線と姿勢配分の定量的な分析を行った が, 実際にどのような視線と姿勢の組み合わせが共起 しているのかは明らかでない, そこで, 漫才の演者達 の視線と姿勢の組み合わせをその向けられた方向から 4 つの非言語行動パターンとして分類し, それらの時 間配分と生起頻度を計測した（表 3，4）。

この分析により, AHKとTRに共通した特徴とし て，BP3が他のパターンと比べて著しく少ないことが 分かる。例えば, AHKではBP3を取る時間長が両者と も全体の $3 \%$ 以下に過ぎず，同様にTRでもほぼ $0 \%$ となり, ッッコミ役のTFに至っては 1 度もBP3を取 らない.

逆に，両者の漫才コンビの違いとして，AHKでは それほど多くないBP4が，TRでは際だって多い体勢 となっている。また, AHKに打いては, 漫才モード では最長パターンであるBP1が，コントモードでは両 者とも $1 \%$ 以下に落ちる点も注目すべき点である。

次に各演者について, 各BP扎よび[その他]の生起 する確率の偏りを $x^{2}$ 検定によって確かめた。なお, AHKについては漫才モードのデータのみを用いた. これはコントモードでは演者がある種の寸劇を行う形 式を取るため(今回のデータでは, コントモードにお いてAHが老人宅を訪問するホームヘルパーを，AKが その老人男性を演じている), 漫才に打ける非言語行 動パターンの分析には不適であると判断したためであ る.

結果はAHに打いてのみ有意差がなく $\left(x^{2}(4)=3.78\right.$, n.s.), 他の 3 人, $\mathrm{AK}\left(x^{2}(4)=23.79, p<.0001\right), \mathrm{TF}$ $\left(x^{2}(4)=66.11, p<.0001\right)$, ТT $\left(x^{2}(4)=93.81, p<\right.$ 
表 3 AHKの非言語行動パターン

\begin{tabular}{|c|c|c|c|c|c|c|}
\hline \multicolumn{2}{|c|}{ 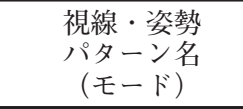 } & $\begin{array}{c}\text { 観客・観客 } \\
\text { BP1 } \\
(\mathrm{M} / \mathrm{C})\end{array}$ & $\begin{array}{c}\text { 相方 } \cdot \text { 相方 } \\
\text { BP2 } \\
(\mathrm{M} / \mathrm{C})\end{array}$ & $\begin{array}{c}\text { 観客・相方 } \\
\text { BP3 } \\
(\mathrm{M} / \mathrm{C}) \\
\end{array}$ & $\begin{array}{c}\text { 相方・観客 } \\
\text { BP4 } \\
(\mathrm{M} / \mathrm{C})\end{array}$ & $\begin{array}{l}\text { その他 } \\
\text { others } \\
(\mathrm{M} / \mathrm{C})\end{array}$ \\
\hline $\mathrm{AH}$ & $\begin{array}{c}\text { 合計時間 } \\
\text { [sec] } \\
\text { 全体比 } \\
\text { (モ上 } 1 \text { 比) } \\
\text { [\%] } \\
\text { 生起頻度 } \\
\text { [回] }\end{array}$ & $\begin{array}{c}81.53 \\
(79.96 / 1.57) \\
19.06 \\
(35.03 / 0.79) \\
36 \\
(33 / 3) \\
\end{array}$ & $\begin{array}{c}143.25 \\
(67.47 / 75.78) \\
33.48 \\
(29.56 / 37.97) \\
51 \\
(26 / 25) \\
\end{array}$ & $\begin{array}{c}12.29 \\
(11.56 / 0.73) \\
2.87 \\
(5.06 / 0.37) \\
24 \\
(21 / 3) \\
\end{array}$ & $\begin{array}{c}61.02 \\
(20.94 / 40.08) \\
14.26 \\
(9.17 / 20.08) \\
66 \\
(31 / 35) \\
\end{array}$ & $\begin{array}{c}129.72 \\
(48.33 / 81.39) \\
30.32 \\
(21.15 / 40.79) \\
98 \\
(33 / 65)\end{array}$ \\
\hline AK & $\begin{array}{c}\text { 合計時間 } \\
\text { [sec] } \\
\text { 全体比 } \\
\text { (モ上比) } \\
\text { [\%] } \\
\text { 生起頻度 } \\
\text { [回] }\end{array}$ & $\begin{array}{c}110.75 \\
(109.65 / 1.10) \\
25.89 \\
(48.04 / 0.55) \\
29 \\
(28 / 1)\end{array}$ & $\begin{array}{c}132.53 \\
(27.89 / 104.64) \\
30.98 \\
(12.22 / 52.43) \\
45 \\
(15 / 30)\end{array}$ & $\begin{array}{c}8.58 \\
(8.58 / 0.00) \\
2.01 \\
(3.76 / 0.00) \\
11 \\
(11 / 0)\end{array}$ & $\begin{array}{c}23.41 \\
(18.50 / 4.91) \\
5.47 \\
(8.11 / 2.46) \\
25 \\
(15 / 10)\end{array}$ & $\begin{array}{c}152.57 \\
(63.63 / 88.94) \\
35.66 \\
(27.88 / 44.56) \\
103 \\
(38 / 65)\end{array}$ \\
\hline
\end{tabular}

表 4 TRの非言語行動パターン

\begin{tabular}{|c|c|c|c|c|c|c|}
\hline \multicolumn{2}{|c|}{$\begin{array}{l}\text { 視線·姿勢 } \\
\text { パターン名 }\end{array}$} & \begin{tabular}{|c} 
観客·観客 \\
BP1
\end{tabular} & $\begin{array}{c}\text { 相方·相方 } \\
\text { BP2 }\end{array}$ & $\begin{array}{c}\text { 観客·相方 } \\
\text { BP3 }\end{array}$ & $\begin{array}{c}\text { 相方·観客 } \\
\text { BP4 }\end{array}$ & $\begin{array}{l}\text { その他 } \\
\text { others }\end{array}$ \\
\hline \multirow{3}{*}{$\mathrm{TH}$} & 合計時間 [sec] & 31.06 & 0.03 & 0.00 & 340.67 & 55.66 \\
\hline & 全体比 [\%] & 7.27 & 0.01 & 0.00 & 79.70 & 13.02 \\
\hline & 生起頻度 [回] & 28 & 1 & 0 & 40 & 25 \\
\hline \multirow{3}{*}{ TT } & 合計時間[sec] & 31.40 & 55.28 & 0.10 & 284.39 & 56.25 \\
\hline & 全体比 [\%] & 7.35 & 12.93 & 0.00 & 66.54 & 13.16 \\
\hline & |生起頻度 [回] & 39 & 10 & 1 & 70 & 40 \\
\hline
\end{tabular}

.0001）ともに有意差があった。

従って, 表 3 の生起頻度から明らかなように, $\mathrm{AH}$ がッッコミ役としてこまめに姿勢・視線を変化させて いる結果として各BPがいずれも頻繁に生じているの に対し, ボケ役のAKでは, BP1の生起頻度がBP3に 比べ有意に高いという傾向がある。この傾向自体は, 有意差は出なかったがAHについても同様である.

一方, TRの二人についてはBP3の生起頻度が極端 に少ない。さらに，TRの特徴として，BP4の生起頻 度もTFが $42.55 \%$ ，TTが43.75\%となっており，時間 長と同様に非常に高いことが確かめられた。

\subsection{3 発話の言語的特徵と非言語行動パターンの分析}

最後の分析として, 発話が言語的に指向する受け手 が観客と相方のどちらであるかと, 各発話が行われて いる時間内で生起する非言語行動パターンとの関係を 調べた。

清原 [17]の観察によれば, ツッコミ発話は原則とし て「です・ます」表現を伴わないとされる。この現象は 本研究のデータにおいても同様の観察結果を得た。し かしながらここで注目すべきなのは，「です・ます」と いう丁寧体表現と「だ・である」調の普通体表現の使い
分けが，発話の指向性を決定する主要因になっている ことである。

例えばAHKのデータでは, 漫才モードにおいて丁 寧体が用いられているのはAHが25発話, AKが27発話 ある(なお，ここでも漫才モードのみを言語的分析の 対象としたのは, コントモードでは演者が演ずる架空 のキャラクター同士の社会的関係によって普通体と丁 寧体が区別される可能性が高いと考えられるためであ る).そしてそのうちAHの 20 発話, AKの 21 発話時に は，視線と姿勢が同時に観客に向けられるBP1が含ま れていた，先の丁寧体発話全体のうち，視線や姿勢が 確認できず[unidentified] タグを付与した発話が，AH では 3 発話, AKでも 1 発話あることを考慮すれば, かなりの割合で丁寧体発話はBP1と相俟って観客を直 接指向していることがわかる.

逆にこのBP1を含む発話を観察すると，上記の丁寧 体表現以外では「ええ」や「はい」などの丁寧体の応答詞 が用いられていることが多い。こうした丁寧体の応答 詞「はいはい」「ええ」やそれに準ずる「ほうほう」や「あ あ」などの間投詞は, 金澤ら [12]が指摘する「合いの手 的」要素の一つと考えられ, 同じく合いの手的要素と なる, 相方による先行発話の一部の「繰り返し」発話が 見られる箇所も含めて頻繁にBP1の体勢が観察でき た。

以上の言語的特徵を考慮して, 以下の 4 つを観客指 向性を示す言語的指標とし，これに従って発話の指向 性 (orientation) タグに[観客]タイプを付与した。

1. 文脈的に明らかに聞き手(観客)に向けられている と分かるもの(例：「いや一会いたかったよ」,

「我々は」)

2.丁寧体の文末(例：「〜です」「〜してください」) 
表 5 AHKの発話の指向性と非言語行動パターンの分 布（漫才モード時のみ）

\begin{tabular}{c|c|c|c|c|c|c|c}
\hline \multicolumn{2}{c|}{ 発話 } & 総数 & BP1 & BP2 & BP3 & BP4 & others \\
\hline \multirow{4}{*}{$\mathrm{AH}$} & 観客指向 & 58 & 48 & 20 & 16 & 9 & 19 \\
& 相方指向 & 46 & 18 & 30 & 3 & 23 & 17 \\
& その他 & 24 & 9 & 13 & 2 & 6 & 9 \\
\hline \multirow{4}{*}{$\mathrm{AK}$} & 観客指向 & 60 & 55 & 10 & 10 & 4 & 22 \\
& 相方指向 & 22 & 12 & 10 & 2 & 6 & 4 \\
& その他 & 35 & 23 & 5 & 0 & 8 & 24 \\
\hline
\end{tabular}

3．丁寧体の応答詞(例：「はいはい」)，または間投詞 の使用(例：「ほうほう」)

4. 先行発話の繰り返し(例：「あのね僕の友達の扎じ いちゃんがね」十「あ, おじいちゃんが」)

そして，上記の言語的指標を持たない発話に対して は，普通体でなされているものに関しては[相方］，断 片的な発話のためどちらの話体であるか確認できない ものについては[その他]のタイプを付与した。このア ノテーションにもとづき, 観客指向発話と相方指向発 話のそれぞれの発話中に扔いてどのような非言語行動 パターンが出現するかを分析した(表 5 )。なお，各 BPについては 1 発話中に複数生起することもあるの で, 発話総数とBPの生起頻度の合計数は一致してい ない。

その結果, $\mathrm{AH}$ の観客指向発話 58 発話中の 48 発話 で, AKの観客指向発話60発話中の55発話に打いて, 視線・姿勢ともに観客を指向するBP1が最も多く含ま れていることが確認された。一方，相方指向発話に関 しては, 必ずしも非言語行動パターンは直接の相方指 向であるBP2が顕著に多いとは言えないことも分かっ た。

上記について確認するため, $\mathrm{AH} \cdot \mathrm{AK} の$ 両演者につ いてそれぞれ $x^{2}$ 検定を行ったところ, $\mathrm{AH}\left(x^{2}(8)=\right.$ $32.67, p<.0001), \operatorname{AK}\left(x^{2}(8)=32.79, p<.0001\right)$ の どちらにおいても, 発話の指向性と非言語行動パター ンとの間の偏りは有意であった。

\section{5. 考察}

5.1 オープンコミュニケーションにおける言語チャネ ルと非言語チャネルの関係

まず，視線と姿勢配分の分析結果から，全体として 漫才対話では「視線が相方, 姿勢が観客」に向けられる 傾向が強いことが観察された ${ }^{8}$.これはオープンコ ミュニケーションの大きな特徵の一つであると考えら れる(図 2 )。

これについて，例えば 1 節で例に出した報道番組，
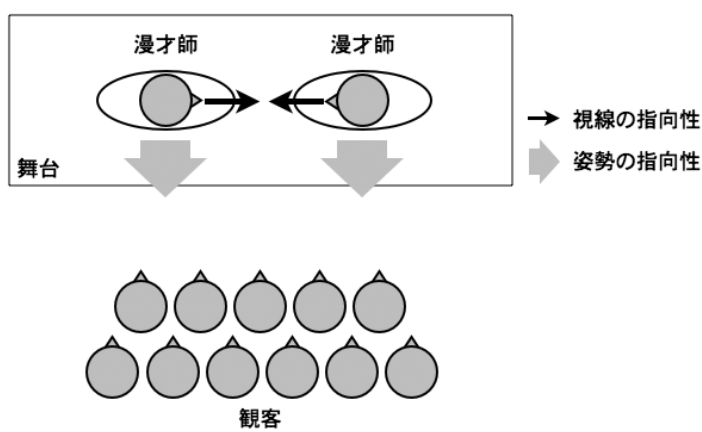

図 2 オープンコミュニケーションの非言語的特徴

さらにはパネルディスカッションなどもオープンコ ミュニケーションの一例と考えることができ, そこで は視聴者や聴衆などのオーディエンスに向かって固定 されたテーブルに着席した状態に打いて視線が対話者 とオーディエンスの間を行き来するので，上記のよう な非言語モダリティ間の特徴は一見自明であるかのよ うに感じる向きもあるだろう。

しかしながら, 漫才という身体動作の自由度が非常 に大きいセッティングに扔いてこの特徵が見られたこ との意義は大きい，言い換えれば，テーブルや椅子と いった制約がなく姿勢を自由に変えることができる立 ち話スタイルであっても, オープンコミュニケーショ ンに拈いては観客への姿勢配分が大きくなることが検 証された。ここにおいて，これまで情報伝達において その役割が見過ごされてきた〈姿勢(ポスチャ)〉に注目 する必要が明らかとなったのである.

一方, 視線についてはTRの分析 (表 2 )では両者と もに $80 \%$ 近く相方に向けられていることが観察された が，AHKのモード別分析からは，漫才モードに限る と特にAKの視線が観客の方に向けられる割合が多い ことが表 1 から観察される。これは一見すると上記の 非言語モダリティ間の特徴と矛盾するように思われ る.

この理由は4.3.3節で明らかにしたように, AHKの 漫才モードでは観客指向発話が多く含まれていること に起因すると考えられる。つまり, 漫才でありながら 明示的に観客に語りかけるスタイルをAKが多用して いることを示しており, この知見も次節で詳細に議論 する，オープンコミュニケーションの持つ外部指向 性〉と〈内部指向性〉の連続的性質を示唆している.

8 実際には4.3.1の最後に触れたように, 漫才モードだけの観察 ではこのような傾向は見られない.しかしながら, 漫才モード とは異なる形ではあるにせよ, コントモード自体も二者間の 対話による外部指向性の顕在化として捉えられるため, 両 モードを合わせた全体的傾向としては矛盾のない特徴と判断 した. 
従って, この非言語モダリティ間の特徵は, 相方と の対話により外部の観客に情報伝達を行うオープンコ ミュニケーションの枠組みから考えると, 視線が直接 の対話者を指向し (=「誰と話すか」)，姿勢が間接的な 情報の受け手を指向している(「「誰に伝えるか」)とい う仮説を立てることができる。この仮説は，次の非言 語行動パターンの分析においても強く示唆される.

非言語行動パターンの分析に扣いて明らかになった のは, 視線と姿勢配分の分析で得られた漫才対話の非 言語モダリティ間の特徴が，時間的に同期した形でも 同様に現れてくることであった．先に 4.2 節で定義し たように演者の視線と姿勢が観客と相方のどちらを指 向しているかを 4 つの非言語行動パターンとして表す と, 先に挙げたオープンコミュニケーションの特徴と はちょうど逆となる「視線が観客, 姿勢が相方」を同時 に実現するBP3は，AHKとTRの両コンビともにほと んど現れなかった。このことは，上記の視線と姿勢の 非言語モダリティの指向的機能についての仮説に対す る一つの傍証となるだろう。

また, 非言語行動パターンから見ると, TRは「視線 が相方，姿勢が観客」を同時に実現するBP4が時間長 においては大部分を占め, 生起頻度でも最頻出パター ンとなっているのに対し，AHKでは，漫才モードに 限ったとしてもそうした傾向を見ることはできなかっ た。この結果は視線と姿勢配分の分析結果と同様に， 最後に行った発話の言語的特徵と非言語行動パターン の関係の分析から説明することができる.

言語的特徵と非言語行動パターンの分析結果による と, AHKでは言語的に観客を指向する観客指向発話 が, 視線と姿勢がともに観客を指向するBP1と共起す ることが非常に多い，特に，観客を指向する最も主要 な言語的指標としての丁寧体に着目すると, AHKで は漫才モードの 228 秒間全般に渡って丁寧体が頻繁に 利用されているのに対し，TRでは開始後 50.5 秒後の TTの「何を買い替えるんっすか」という発話を最後 に, TFの1発話を除いた残りの376.5秒間の全てが普 通体での対話となっている.

このことから AHKでは言語的にも非言語的にも 観客を指向する「内部指向的発話」も多く用いられるの に対し，TRでは言語的には観客指向でない発話を， 非言語チャネルにおいて姿勢を観客に向けることによ り，非明示的な観客指向性，つまり「外部指向性」を実 現させていることが分かる.

こうした言語チャネルと非言語チャネルの乘離によ る外部指向性の顕在化は, AHKでは相方指向発話に おいて観察することができる。前節で述べたように， 言語的に相方を受け手に指定する相方指向発話に対し
ては必ずしもBP2が共起しない。これは漫才対話が二 者間の単なる閉じられた対話と異なり，発話の指向性 が言語・非言語モダリティにおいて一致する程度が低 いことを示唆している.

\section{2 複数のモダリティをまたぐ動的参与構造}

これまでの分析により, 古典的なしゃべくり漫才の $\mathrm{AHK}$ 現代的な漫才スタイルを持つTRを比較する と, 観客に直接語りかける一方, 逆に相方に対して ッッコミを入れたり相桘を入れたりすることで対話の 指向性を動的に変化させる前者と, 相方との閉じた対 話でありながら観客指向の非言語行動パターンを用い ることで静的にオープンコミュニケーションを実現す る後者とで対照的なコミュニケーションスタイルを観 察することができた。しかし，こうしたマクロな観察 からは窺い得ない細かなインタラクションについても 分析が必要である。

ここでAHKの漫才モードにおける一発話の中で生 じているマルチモーダルな参与構造について観察して みる。図 3 は今回のデータに打いて, 開始28.95秒後 から30.65秒後までの $1707 \mathrm{~ms}$ 間にAHが発した「何をす すめとんのやほんまにねえ」という発話区間において の二人のマルチモーダルなインタラクションをモデル 化したものである。

この発話に先立つ文脈として，まずボケ役の $\mathrm{AK}$ が，冒頭の気候の挨拶に引き続いて，最近寒くなった ので老人がポックリ亡くなってしまうことが多いとい う話を出し，観客に対して「今がチャンスですよ」とい う不謹慎な発言を行う。それに対してAHが「うわ, 何 をすすめとんだ」という驚きの発話を行い，それに続 く形で「何をすすめとんのやほんまにねえ」 $\left(\mathrm{U}_{1}\right)$ とい う発話を行っている場面である。罒 3 はこの $U_{1}$ が発 話されている区間に扔いて両者の発話の指向性と非言 語動作の組み合わせが変化していく様子を $\mathrm{P}_{1}$ から $\mathrm{P}_{5}$ までの 5 つのフェーズとして捉えている。 なお， $\mathrm{P}_{1}$ か ら $\mathrm{P}_{5}$ までの各フェーズの時間長は $577 \mathrm{~ms}, 234 \mathrm{~ms}$, $241 \mathrm{~ms}, 126 \mathrm{~ms}, 529 \mathrm{~ms}$ あ゙る.

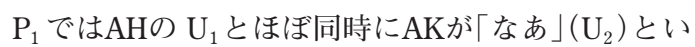
う短い応答を行っている。このとき, 両者とも姿勢 · 視線が相方に向けられるBP2の体勢を取っている. 次 に $\mathrm{P}_{2}$ においてAKが視線のみを観客に向けながら (BP3)，「いやほんまに元気な方がよろしいけどね」

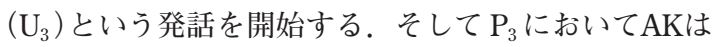
姿勢も観客に向き直り $(\mathrm{BP} 1)$ その発話を継続する。 そして $\mathrm{P}_{4} に お い て A H も$ 視線を先行させる形で (BP3) 発話を継続し, 最後に $\mathrm{P}_{5}$ に打いて姿勢・視線とも観 客に向き直ることで発話を完結する（BP1）。 
このとき発話の指向性について観察すると, 4.3 .3 節での基準に従えば, $\mathrm{AK} の \mathrm{U}_{2}$ は普通体での応答であ ると考えられるので，相方のAHに向けられたもので あると考えられる。そして, 続く $\mathrm{U}_{3}$ の発話は「よろし いけどね」という丁寧体でなされているため観客指向 の発話であると考える。しかし，AHの「何をすすめと んのやほんまにねえ」という発話は，発話区間におい てBP2 $(1052 \mathrm{~ms}) \rightarrow \mathrm{BP} 3(126 \mathrm{~ms}) \rightarrow \mathrm{BP} 1(529 \mathrm{~ms})$ と いう形で 3 段階の変化を見せており，前半部分が相方 に向けられているッッコミであるのに対し，後半部分 は明らかに観客への同意を促す発話となっていること がわかる。なお，図 3 で $\mathrm{P}_{4}$ における発話の指向性を 表す矢印が方向性を持たない破線として表されている のは, 発話の途中段階での指向性の特定が不可能であ ることを示している.

このような極めて短いインタラクションの観察から 以下のような知見が得られる。

・ 1 つの発話中に打いても発話の指向性は変化し得 る

・言語・非言語の各モダリティの指向性の変化は必 ずしも時間軸上で同期しない

・視線と姿勢の指向性を同一の方向に変化させると きは，視線が姿勢に先行して生じる場合が多い

最初の知見からは発話の指向性の特定が非言語チャネ ルとは異なる形で困難を抱えていることが浮き彫りと なる。この点については特に発話と視線との同期・非
同期について詳細な分析が必要となるであろう。そし て2つ目の知見からは, 本稿の目的であるオープンコ ミュニケーションの外部指向性や内部指向性が離散的 なものではなく，2 節で述べたようなグレイディエン スを持った連続的なものであることを示唆している.

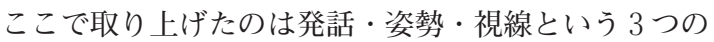
モダリティの指向性であるが，それぞれをパラメータ とした関数としてオープンコミュニケーション自体の 指向性を捉え，元の特定がいかにして可能となるかに ついても更なる分析が必要であろう。そして最後の知 見からは4.3.2節で述べたように「視線が観客, 姿勢が 相方」を同時に実現するBP3の継続時間が他の非言語 行動パターンに比して顕著に少ないこと，およびその 生起パターンが限定的である根拠を示していると考え られる。つまり，BP3はBP2からBP1への遷移に打い て過渡的な段階として生じていることが多いのであ る。実際，AHKの漫才モードにおいてBP3が生じてい る際の前後の非言語パターンを分析すると, 合計 31 回 のBP3の生起において実に25回は, 先述のBP2 $\rightarrow$ BP3 $\rightarrow B P 1$ という遷移パターンとして生じている.

このようにAHKによる漫才のやり取りについてミ クロな分析を行った結果, オープンコミュニケーショ ンの一つのあり方として, 対話者と観客の間の動的な 参与構造の存在が浮かび上がった。それは一方では対 話者間のボケやッッコミなどの会話のやり取りを通じ て間接的に外部の観客への情報伝達を指向しつつ，も う一方では直接的に観客に対して語りかけたり共感を 促したりする形での内部指向性の顕在化であり，その


図 3 マルチモーダルな指向性の動的変化 
二つの指向性が演者間のインタラクションのみなら ず，一つの発話内でも動的に変化しているという構造 である。こうした動的な参与構造の変化が言語と複数 の非言語モダリティの非同期的遷移に基づいて生じて いることは, 今後オープンコミュニケーション構造を 精緻化し，二者間の対話に基づく教示エージェントモ デルを構築する上で重要な視点となるであろう.

\section{6. まとめと今後の課題}

まとめると, AHKは言語チャネルと非言語チャネ ルの両方で観客を指向する内部指向的発話を多く利用 しながらも，言語的に相方に向けられた発話では非言 語チャネルを観客に開くことによって外部指向性を実 現している。一方TRは, 金澤ら [16]が指摘するよう に日常の若者同士の会話に見られる「うん」や「あ一」と いったうなずきを多用し, 丁寧体をほとんど用いずに 普通体での会話を進めることによって, ダウンタウン 以降の漫才師の特徵である日常会話的な身近さを生み 出しつつも, 視線と姿勢をずらしたBP4という非言語 的装置を中心的に利用することで，こうした言語的な 相方指向を上手く観客への外部指向性に変換している と言える.

このようにオープンコミュニケーションに打ける外 部指向性と内部指向性は, さまざまな文法的要素から なる言語的装置と, 視線や姿勢などの異なるモダリ ティの同期・非同期に基づく非言語的装置との相互作 用によって緩やかに顕在化する。従って, 対話型教示 エージェントモデルを構築するためには, 単なる閉じ られた 2 者間の対話モデルを適用するのではなく, ユーザに明示的に語りかける場面に打いては非言語 チャネルの指向性を同調させることで内部指向性を実 現させる一方，対話相手のエージェントに向けた発話 では基本的に視線を同調させつつ姿勢をユーザに向け るような外部指向性の実現が求められる.

以上の分析は, 扱うデータの数, ならびに言語的・ 非言語的指標の不足など様々な問題を残している. 特 に, 本稿の分析結果や仮説は今回取り上げた二組の漫 才コンビにのみ妥当するものである可能性も完全には 否定できない。従って, 我々は既に, 他の複数の漫才 コンビのDVD映像のアノテーションも進めており, さらには複数台のカメラやマイクを用いて実際に漫才 コンビをいくつか招聘して収録を行った映像のコーパ ス化にも取りかかっている.

さらに，5.2節で指摘したように漫才内における非 言語行動パターンの遷移についてもより詳細に分析す る必要があろう。また, 本稿では漫才の演者の個人内 における発話と非言語モダリティの相互関係に注目し
たが，対話者間における発話と非言語行動の関係を明 らかにすることも同様に進めて行きたい。さらに，そ うした対話者間の非言語行動の遷移という相互行為的 な側面については, Kendon[20]で提起されたF陣形 (F-formation) との関連性も念頭に置いて分析を進め る予定である。

そして，オープンコミュニケーションの外部指向性 や内部指向性を明確に規定するためには, 今回は分析 できなかったコントや演劇などとの比較，さらには日 常会話に打ける閉じられた二者間対話との比較も有効 であると考えられる。いわる日常的な「立ち話」と漫 才は何がどう異なっており, 同時にどのような共通性 を持っているのであろうか.

一方, 本研究で目標として揭げる対話型教示エー ジェントモデルの構築を目指す上では, 教示テキスト を入力として与えた時に, どうやって自動的に対話化 を行い, どの発話をどちらのエージェントに割り振 り, どうやって各発話の適切な受け手を指定するか, などを明らかにすることも将来的に必要である。ま た, 教示システムという観点からは, 単一のエージェ ントによる情報提供システムとの比較実験を通して, 本研究で提案しようとする対話型教示エージェントシ ステムの教示効果を検証する必要もある。ささらに, 本 稿で示唆された内部指向性と外部指向性のグレイディ エンスが，どのように教示エージェントシステムのデ ザインに有効となるかも検証せねばなるまい。これに ついては, 実際に対話型擬人化エージェントを用いた 教示コンテンッを作成し, 本稿で明らかにしたオープ ンコミュニケーションの内部指向性と外部指向性の心 理的効果について検証することを検討している.

今後は, 本稿で提起したくオープンコミュニケー ション>の枠組みをさらに精緻化し，こうした様々な 観点からより多くのデータ分析とシステムの実装, お よび検証実験等を行うことによって, 上記の課題に対 して逐次取り組んで行きたい.

\section{謝辞}

本稿の執筆に当たり, まずは静岡大学の竹内勇剛准 教授ならびに匿名の査読者諸氏に多数の有益なコメン 卜を得たことに対し, この場を借りて深く感謝する。 そして, 研究遂行に際し, アノテーションを含めて多 大なる助力を頂いた東京工科大学メディア学部の櫻井 章仁君, ならびに森田庸介君にも感謝したい。最後 に, 法律の専門家の立場から, 本稿での著作権ならび に肖像権について適切な助言を頂いた, 石本茂彦氏を 始めとする森・濱田松本法律事務所の弁護士諸氏にも 心からの感謝を捧げる。 
なお本研究は, 日本学術振興会科学研究費補助金 (萌芽研究：19650045) および文部科学省私立大学学 術研究高度化推進事業オープンリサーチセンター整備 事業「再利用可能な協働効果型オープンメディアリ ソース研究・構築プロジェクト」の助成を受けて行わ れた。

[1] http://www.ananova.com/video/

[2]嵯峨山茂樹, 川本真一, 下平博, 新田恒雄, 西本卓也, 中村哲, 伊藤克亘, 森島繁生, 四倉達夫, 甲斐充彦, 李晃伸, 山下洋一, 小林隆夫, 徳田恵一, 広瀬啓吉, 峯松信明, 山田篤, 伝康晴, 宇津吕武仁：擬人化音声 対話エージェントッールキットGalatea, 情報処理学 会研究報告, 2002-SLP-45-10（2003）， pp.57-64.

[ 3 ] Cassell, J., Bickmore, T., Billinghurst, M., Campbell, L., Chang, K., Vilhjálmsson, H., and Yan, H.: Embodiment in Conversational Interfaces: Rea, ACM SIGCHI, ACM Press (1999), pp.520-527.

[ 4 ] Cassell, J., Stocky, T., Bickmore, T., Gao, Y., Nakano, Y., Ryokai, K., Tversky, D., Vaucelle, C., Vilhjálmsson, H.: MACK: Media lab Autonomous Conversational Kiosk, Proceedings of Imagina '02, February 12-15, Monte Carlo (2002).

[5] 久保田秀和, 山下耕二, 福原知宏, 西田豊明: POC caster:インターネットコミュニティのための会話表現 を用いた情報提供エージェント, 人工知能学会論文誌, Vol.17, No.3 (2002), pp.313-321.

[6] 久保田秀和, 黒橋禎夫, 西田豊明: 知識カードを用い た分身エージェント，電子情報通信学会論文誌「ソフ トゥェアエージェントとその応用論文特集」,VolJ86D-I, No.8 (2003), pp.600-607.

[ 7 ] Clark, H. H. and Carlson, T. B.: Hearers And Speech Acts, Language, 58 (1982), pp.332-373.

[ 8 ] Okamoto, M., Nakano, Y. I., and Nishida, T.: Toward Enhancing User Involvement via Empathy Channel in Human-Computer Interface Design, In L. Bolc et al. (Eds.) : Lecture Notes in Computer Science Vol.3490, Intelligent Media Technology for Communicative Intelligence, Springer-Verlag GmbH (2005), pp.111-121.

[9]林宏太郎, 神田崇行, 宮下敬宏, 石黒浩, 荻田紀博： ロボット漫才ー社会的受動メディアとしての二体のロ ボットの利用一, 日本ロボット学会誌, Vol.25, No.3 (2007), pp.57-65.

[10］スコギンズ・リーバイ, 川嶋宏彰, 松山隆司：間の合っ
た発話タイミング制御を目的とした漫才の動的構造の 分析, インタラクション 2005, D-404.

[11］川嶋宏彰, スコギンズ・リーバイ，松山隆司：漫才の 動的構造の分析一間の合った発話タイミング制御を目 指して一, ヒューマンインタフェース学会誌, Vol.9, No.3 (2007), pp.379-390.

［12］渡辺富夫, 大久保雅史, 小畑淳 : 集団コミュニケー ション場の生成のための音声駆動型身体引き込みシス テムの開発,ヒューマンインタフェース学会研究報告 集, Vol.2, No.3 (2000), pp.43-46.

[13] Watanabe, T., Okubo, M., Nakashige, M., Danbara, R.: InterActor: Speech-Driven Embodied Interactive Actor, International Journal of Human-Computer Interaction, Vol.17, No.1 (2004), pp.43-60.

[14］山本倫也, 渡辺富夫：音声駆動型身体引き込みキャラ クタを映像に重畳合成した教育支援システム, 情報処 理学会論文誌, Vol.47, No.8 (2006), pp.2769-2778.

[15] Okamoto, M., Nakano, Y. I., Okamoto, K., Matsumura, K., and Nishida, T.: Producing Effective Shot Transitions in CG contents Based on a Cognitive Model of User Involvement, Special Section of Life-like Agent and its Communication, IEICE Transactions of Information and Systems, Vol.E88- D, No.11 (2005), pp.25232532 .

[16］金澤裕之, 橋本直幸: 漫才の言語特徵, 月刊言語, 2005 年 1 月号 (2005), pp.46-53.

［17］清原裕登:「笑い」を誘う言葉一上方漫才に打けるコン ビと聴衆の相互関係一, 社会言語科学会第19回大会発 表論文集 (2007), pp.46-49.

[18] http://sourceforge.net/projects/agtk/

[19] http://www.dfki.de/ kipp/anvil/

[20] Kendon, A.: The role of visible behaviour in the organization of social interaction, In Cranach, M.V. and Vine, I. (Eds): Social Communication and Movement: Studies of Interaction and Expression in Man and Chimpanzee, New York: Academic Press (1973), pp.2974 .

(2007年12月27日 受付)

(2008年 5 月 12 日 採録)

[問い合わせ先]

テ192-0982 八王子市片倉町1404-1

東京工科大学片柳研究所 メディアテクノロジーセンター 岡本 雅史

TEL：042-637-2111(代) 6041(内線)

E-mail : okamotoma@media.teu.ac.jp 




帮热毕雅史 [非会員]

1996 年京都大学大学院人間・環境 学研究科修士課程修了. 1999 年同大 学院同研究科博士後期課程単位取得認 定退学. 1996 年日本学術振興会特別 研究員, 2002 年東京大学大学院情報 理工学系研究科学術研究支援員を経 て, 2006 年 4 月より東京工科大学片 柳研究所客員准教授. 博士 (人間 - 環 境学). 言語学 (認知言語学／語用論) およびコミュニケーション研究に従 事. 電子情報通信学会 HCG 第 3 種研 究会ヴァーバル・ノンヴァーバル・コ ミュニケーション研究会委員長. 日本 認知言語学会, 日本語用論学会, 日本 言語学会, 社会言語科学会他, 各会 員.



榎杂 美香 [非会員]

2007 年千葉大学大学院自然科学研 究科博士後期課程修了. 2000 年ATR 知能映像通信研究所研修研究員, 2004 年千葉大学文学部学術研究支援 員, 2006 年東京農工大学工学府 ·工学 部産学官連携研究員, 2007 年東京工 科大学片柳研究所嘱託研究員を経て, 2008 年東京工科大学メディア学部助 教. 博士 (学術). 言語心理学の立場 から, 会話に打ける聞き手の行動・認 知メカニズムの解明に取り組む. 社会 言語科学会企画委員会委員. 電子情報 通信学会 $\mathrm{HCG}$ 第 3 種研究会ヴァーバ ル・ノンヴァーバル・コミュニケー ション研究会専門委員. 日本心理学 会, 社会言語科学会, 日本認知科学 会, 人工知能学会各会員.

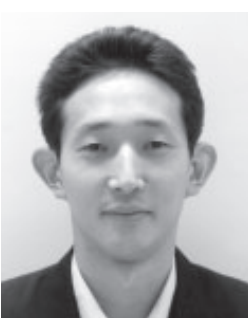

大庭 颠人 $[$ 非会員]

2001 年 3 月京都大学大学院情報学 研究科修士課程修了。2004 年 3 月同 大大学院博士課程満期退学 (単位取 得). 2004 年 4 月より東京工科大学メ ディア学部助手, 2008 年 4 月より同 大片柳研究所嘱託研究員. カテゴリ特 異的な失語症の症例シミュレーション 研究, および文理解の fMRIによる脳 計測研究, また近年は漫才に打ける観 客とのインタラクションの研究にも従 事. 日本認知心理学会, 日本心理学 会, 日本高次脳機能障害学会, 各会 員.

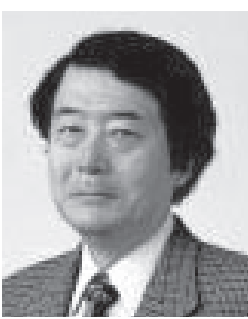

飯苗仁 [非会員]

1974 年早稲田大学大学院理工学研 究科数学専攻修了. 日本電信電話公社 （現 NTT）基礎研究部, NTT基礎研究 所, ATR自動翻訳電話研究所, ATR音 声翻訳通信研究所, ソニーCSL等を 経て, 2003 年 4 月より東京工科大学 メディア学部教授、博士 (工学)。言 語処理学会元会長, アジア太平洋機械 翻訳協会副会長. 科学技術庁長官賞等 受賞. 音声対話理解・翻訳, マルチモー ダル・インタラクション, 感性コミュ ニケーション等の研究・教育に従事. 


\title{
Multimodal Analysis of Manzai Dialogue Toward Constructing a Dialogue-Based Instructional Agent Model \\ by
}

\author{
Masashi OKAMOTO, Masato OHBA, Mika ENOMOTO and Hitoshi IIDA
}

\section{Abstract :}

Our research aims at constructing a dialogue-based instructional agent model. To achieve the goal, we propose an 'open communication' model as a novel framework for instructional contents, and analyze the interrelations among verbal and non-verbal modalities (speech/gaze/posture) in manzai dialogues. In particular, focusing on inward or outward- oriented function of open communication, we analyzed two video contents of manzai dialogues and explored how multimodal behaviors and interactions of the two pairs of laughmakers realized either of the communicative functions. As a result, we found that the ways of realizing the communicative orientedness differed between the pairs of laughmakers in manzai dialogue based on the interrelations of their speech and multimodal behaviors.

Keywords : manzai dialogue, open communication, multimodality, outward-orientedness, dialogue-based instructional agent

\section{Contact Address : Masashi OKAMOTO}

Katayanagi Advanced Research Laboratories, Tokyo University of Technology

1404- 1 Katakura-cho, Hachiouji-shi,Tokyo 192-0982, JAPAN

TEL : 042-637-2111 (6041)

E-mail : okamotoma@media.teu.ac.jp 